Article

\title{
Phylogenetic and Geospatial Evidence of Canine Parvovirus Transmission between Wild Dogs and Domestic Dogs at the Urban Fringe in Australia
}

\author{
Mark Kelman ${ }^{1, *(\mathbb{D}, \text { Lana Harriott }}{ }^{2}$, Maura Carrai ${ }^{1,3}$, Emily Kwan ${ }^{1}$, Michael P. Ward ${ }^{1}$ (D) \\ and Vanessa R. Barrs 1,3 (D) \\ 1 Sydney School of Veterinary Science, The University of Sydney, Sydney, NSW 2006, Australia; \\ maura.carrai@sydney.edu.au (M.C.); emilypkwan2.7@gmail.com (E.K.); \\ michael.ward@sydney.edu.au (M.P.W.); vanessa.barrs@cityu.edu.hk (V.R.B.) \\ 2 Pest Animal Research Centre, Biosecurity Queensland, Department of Agriculture and Fisheries, \\ Toowoomba, QLD 4350, Australia; Lana.Harriott@daf.qld.gov.au \\ 3 Jockey Club College of Veterinary Medicine, City University of Hong Kong, Kowloon Tong, Hong Kong, \\ China \\ * Correspondence: kelmanscientific@gmail.com
}

Received: 21 May 2020; Accepted: 17 June 2020; Published: 19 June 2020

check for updates

\begin{abstract}
Canine parvovirus (CPV) is an important cause of disease in domestic dogs. Sporadic cases and outbreaks occur across Australia and worldwide and are associated with high morbidity and mortality. Whether transmission of CPV occurs between owned dogs and populations of wild dogs, including Canis familiaris, Canis lupus dingo and hybrids, is not known. To investigate the role of wild dogs in CPV epidemiology in Australia, PCR was used to detect CPV DNA in tissue from wild dogs culled in the peri-urban regions of two Australian states, between August 2012 and May 2015. CPV DNA was detected in 4.7\% (8/170). There was a strong geospatial association between wild-dog CPV infections and domestic-dog CPV cases reported to a national disease surveillance system between 2009 and 2015. Postcodes in which wild dogs tested positive for CPV were 8.63 times more likely to also have domestic-dog cases reported than postcodes in which wild dogs tested negative ( $p=0.0332$ ). Phylogenetic analysis of CPV VP2 sequences from wild dogs showed they were all CPV-2a variants characterized by a novel amino acid mutation (21-Ala) recently identified in CPV isolates from owned dogs in Australia with parvoviral enteritis. Wild-dog CPV VP2 sequences were compared to those from owned domestic dogs in Australia. For one domestic-dog case located approximately $10 \mathrm{~km}$ from a wild-dog capture location, and reported 3.5 years after the nearest wild dog was sampled, the virus was demonstrated to have a closely related common ancestor. This study provides phylogenetic and geospatial evidence of CPV transmission between wild and domestic dogs in Australia.
\end{abstract}

Keywords: canine parvovirus; peri-urban; wild dogs; disease transmission; Australia

\section{Introduction}

Canine parvovirus (CPV) is a single-stranded DNA virus belonging to the family Parvoviridae, subfamily Parvovirinae, genus Protoparvovirus and species Carnivore Protoparvovirus 1 (CPPV-1) [1]. CPV infection occurs worldwide and has been reported in a range of carnivores, including domestic dogs and various wildlife species [2-11]. Viruses closely related to CPV include Feline parvovirus (FPV), Mink enteritis virus (MEV), Blue fox parvovirus (BFPV) and Racoon parvovirus (RPV) [12,13], so named due to their initial detection in these species. Clinical disease caused by Carnivore protoparvovirus 1 in 
different host species ranges from asymptomatic to severe gastroenteritis, leukopenia, dehydration and death [14].

Although the exact origin of CPV remains unknown, CPV is thought to have evolved from FPV, or, more likely, that both viruses share a common ancestor that is likely associated with a wild carnivore host [12,13,15-19]. CPV poses a continuing threat for the emergence of new variants with pathogenic potential for multiple carnivore species in the order Carnivora.

Across Australia, CPV disease is relatively common in owned domestic dogs, particularly in rural and remote regions. An estimated 20,000 cases occur annually in Australia, with a reported incidence of 4.12 cases per 1000 dogs [20,21]. CPV infection has also been reported in wild canids, including four dingoes (Canis lupus dingo) (including a litter of three dingo puppies) and a dingo-dog hybrid, based on fecal antigen testing [10], as well as a red fox (Vulpes vulpes), based on serological testing [22]. However, the presence of CPV in Australian wild dogs has not been investigated. Wild and feral dogs are distributed throughout Australia, ranging from remote, isolated regions to peri-urban areas [23], though wild-dog numbers are not well documented [24].

In Australia, the term "wild dog" includes dingoes, feral domestic dogs (Canis familiaris) and hybrids [25]. The only other wild canid in Australia is the red fox, Vulpes vulpes, which was introduced as a result of European settlement [26]. The other feral carnivore in Australia is the feral cat, Felis catus [27], which is a likely parvovirus reservoir, given that FPV and CPV have been demonstrated in the Australian feral cat population [28-30]. Domestic dogs are also suggested as likely reservoir hosts for CPV in Africa, China and Mexico [31-34]. Furthermore, molecular investigations of CPV have provided evidence of cross-species bidirectional transmission between domestic dogs and wild carnivores [15,32]. While an epidemiological association between CPV case-occurrence in domestic dogs and geographical proximity to wild dogs and foxes in Australia has been reported [10], evidence of infection with the same or related strains of CPV is lacking. Peri-urban regions in Australia are a likely location to detect the presence of CPV in wild dogs, as there is close contact between human settlements and wild carnivore populations, which has been associated with exposure to CPV [32,35,36].

As well as being present in blood and feces during active infection, parvoviruses persist in mononuclear cells in peripheral blood or tissue $[29,37]$ after fecal shedding of virus has ceased. This allows tissue samples to be used to detect both active and resolved infections in asymptomatic hosts that are no longer shedding virus in feces, and which likely represent latent infection, as reported for human parvoviruses [12,38]. CPV has been detected in wild carnivores and domestic cats, in a range of tissue samples after viral shedding has ceased, including blood, bone marrow, mesenteric lymph nodes, tongue, spleen and myocardium [12,29,37].

Our goal was to investigate the epidemiology of parvoviruses at the wild-domestic dog interface. The specific objectives of this study were to determine whether wild-dog populations in Australia are exposed to CPV, and if so, to estimate its prevalence and identify circulating strains; and to assess the likelihood of transmission of CPV between wild dogs and domestic dogs in peri-urban regions.

\section{Materials and Methods}

\subsection{Wild-Dog Sample Collection}

The carcasses of 201 wild dogs captured and culled between August 2012 and May 2015 from peri-urban regions of South East Queensland (SEQ) and Northern New South Wales (NSW) were supplied by local councils, for a study investigating pathogens of public health or economic significance [24]. Ethics approval was granted by the University of Queensland AEC (Animal Ethics Committee) (SVS/145/13). Residual tissue samples (tongue), which had been stored frozen at $-18^{\circ} \mathrm{C}$, were made available for CPV testing. 


\subsection{DNA Extraction and Conventional PCR}

DNA was extracted from tongue tissue for PCR, using the Macherey-Nagel mini kit (Macherey-Nagel, Düren, Germany). To evaluate the presence and quality of canine DNA, a conventional PCR was performed, targeting a canine housekeeping gene, the ribosomal protein L32 (RPL32) gene, using the following primers: RPL32-F (5'- ACCTCTGGTGAAGCCCAAG-3') and RPL32-R (5'GGGATTGGTGACTCTGATGG-3') [39]. The total reaction volume was $25 \mu \mathrm{L}$ and contained $2.5 \mu \mathrm{L}$ of template DNA, $0.5 \mu \mathrm{L}$ each of forward- and reverse-primer, $0.5 \mu \mathrm{L}$ of MyTaq ${ }^{\mathrm{TM}} \mathrm{HS}$ Red DNA Polymerase, $5 \mu \mathrm{L}$ of MyTaq ${ }^{\mathrm{TM}}$ Red Reaction Buffer and $16 \mu \mathrm{L}$ of water. DNA amplification was performed by using an initial denaturation step at $95^{\circ} \mathrm{C}$ for $1 \mathrm{~min}$, followed by 35 cycles of $95^{\circ} \mathrm{C}$ for 15 $\mathrm{s}, 60{ }^{\circ} \mathrm{C}$ for $15 \mathrm{~s}$ and $72{ }^{\circ} \mathrm{C}$ for $10 \mathrm{~s}$, with a final extension step at $72{ }^{\circ} \mathrm{C}$ for $5 \mathrm{~min}$. Following PCR, the samples were electrophoresed on a $1 \%$ agarose gel (Bio-Rad Laboratories, Hercules, CA, USA), using $1 \times$ tris-borate EDTA running buffer, and visualized with SYBR safe DNA (Thermo Fisher Scientific, Waltham, MA, USA).

\subsection{Real-Time PCR}

Real-time PCR/quantitative PCR assay (qPCR) was performed to determine the CPV viral load in DNA extracts from tongue tissue of the wild-dog cadavers, as previously described, with minor modification [40]. In brief, real-time PCR was carried out in a $35 \mu \mathrm{L}$ reaction containing $17.5 \mathrm{~mL}$ of IQ Supermix (Bio-Rad Laboratories Srl), $600 \mathrm{nM}$ of primers CPV-For and CPV-Rev, $200 \mathrm{nM}$ of probe CPV-Pb (Table 1), and $10 \mu \mathrm{L}$ of template (diluted 1:10 in Tris EDTA buffer). Serial 8-fold dilutions (representing from $10^{9}$ to $10^{2}$ DNA copies/10 $\mu \mathrm{L}$ ) of a plasmid, pFastBac ${ }^{\mathrm{TM}} \mathrm{HTA}$, containing VP2 gene sequence were used to generate a standard curve. Each test sample and each dilution of standard DNA was tested in duplicate. An exogenous DNA internal control, Cal Orange 560 (Bioline, Meridian Bioscience, Cincinnati, OH, USA), was added to each sample, in order to control for PCR inhibition, according to the manufacturer's instructions. The thermal-cycle protocol used was the activation of Taq DNA polymerase at $95^{\circ} \mathrm{C}$ for $10 \mathrm{~min}$ and 40 cycles consisting of denaturation at $95^{\circ} \mathrm{C}$ for $15 \mathrm{~s}$, primer annealing at $52{ }^{\circ} \mathrm{C}$ for $30 \mathrm{~s}$ and extension at $60^{\circ} \mathrm{C}$ for $1 \mathrm{~min}$. All reactions were conducted in an a CFX connect ${ }^{\mathrm{TM}}$ Real Time PCR Detection System (Bio-Rad Laboratories Pty., Ltd. Gladesville, Australia), and the data were analyzed with the software CFX Maestro. Samples were considered positive only when results could be confirmed from paired testing in a single assay.

Table 1. Sequence and position of oligonucleotides used in the study [40] *.

\begin{tabular}{|c|c|c|c|c|c|}
\hline Assay & Primer/Probe & Sequence $5^{\prime}-3^{\prime}$ & Polarity & $\begin{array}{l}\text { Amplicon } \\
\text { Size (bp) }\end{array}$ & Position ${ }^{\dagger}$ \\
\hline \multirow{3}{*}{$\begin{array}{l}\text { Real Time } \\
\text { Assay }\end{array}$} & CPV-For & AAACAGGAATTAACTATACTAATATATTTA & + & 93 & $4104-4135$ \\
\hline & CPV-Rev & AAATTTGACCATTTGGATAAACT & - & & $4176-4198$ \\
\hline & $\mathrm{CPV}-\mathrm{Pb}$ & $\begin{array}{c}\text { TGGTCCTTTAACTGCATTAAATAATGTACC- } \\
\text { TAMRA }\end{array}$ & -+ & & $4143-4172$ \\
\hline
\end{tabular}

${ }^{*}$ FAM 5 6-carboxyfluorescein; TAMRA 5 6-carboxytetramethylrhodamine. ${ }^{\dagger}$ Oligonucleotide position is referred to the sequence of strain CPV-b (accession M38245).

\subsection{Conventional PCR and Sequence Analysis}

Samples testing positive for CPV in the qPCR assay were subject to conventional PCR and sequencing of the complete VP2 gene, as previously described [30,41].

The VP2 sequences from wild dogs were assembled and aligned, using CLC Workbench (Qiagen, Hilden, Germany), and then compared to previously characterized VP2 sequences from domestic dogs in Australia [42] and other countries, as well as reference strains of CPV, including CPV-2a-like and related viruses obtained from the GenBank database. Sequences were aligned by using the Geneious prime software package (11.0.4) using the MAFT algorithm. Phylogenetic analysis was performed using Mega X version 10.0.5 and employing the Tamura 3-parameter model of nucleotide substitution 
using a discrete gamma distribution $(+G)$ and assuming that a certain fraction of sites is evolutionarily invariable $(+I)$, with the Nearest-Neighbor Interchange heuristic method. The Tamura 3-parameter $+G$ $+I$ model provided the best maximum likelihood (ML) fit of 24 nucleotide substitution models, with a Bayesian Information Criterion Score of 9996.026. The analysis involved 78 nucleotide sequences. Codon positions included were $1 \mathrm{st}+2 \mathrm{nd}+3 \mathrm{rd}+$ Noncoding. There were a total of 1719 positions in the final dataset.

\subsection{Wild-Dog Sample Data and Owned-Dog CPV Case Occurrence Data}

Data collected at the time each wild dog was culled included, sex, estimated age (from examination of dentition), date of capture, and latitude and longitude of capture location. These data were used in geospatial and statistical analysis. Eight samples missing data for date of capture or capture location were excluded from the analysis.

Retrospective data on owned-dog CPV cases occurring in the same postcodes in which wild-dog samples were collected were obtained to evaluate the potential for CPV transmission between wildand owned-dog populations. Data from 2009 to 2015 were sourced from the Disease WatchDog ${ }^{\circledR}$ database [43], a collection of national disease surveillance data for companion animals in Australia (http://www.vetcompass.com.au). Only cases that had been confirmed by diagnostic testing (fecal antigen test "ELISA", PCR or immunofluorescence) were included in our analysis. For the purpose of geospatial and statistical analysis, only data relating to the case date (year) and postcode were used.

\subsection{Geospatial Analysis of Wild-Dog Data and Owned-Dog Data}

Mapping and geospatial analysis were performed, using ArcGIS ${ }^{\circledR}$ version 10.2 (ERSI, Redlands, CA). Wild dogs' positive and negative results were mapped by nearest postcode, which was identified from supplied latitude and longitude location data, in ArcGIS, using an ABS Postal Areas ASGS Ed 2016 Digital Boundaries Shapefile (ESRI Format) [44]. Owned-dog case occurrence was mapped by postcode. Maps were generated at the state level for SEQ and Northern NSW, and also at a regional level for Brisbane and south of Brisbane, to the border of Queensland (QLD) and NSW.

\subsection{Statistical Analysis of Domestic-Dog CPV Cases and Association with Wild-Dog Infection}

Data were analyzed by using Microsoft ${ }^{\circledR}$ Excel for Mac Version 16.16 .15 and Statistix ${ }^{\circledR}$ version 10.0 (Analytical Software, Tallahassee, FL, USA). Odds ratios were calculated for the frequency of postcodes with wild dogs testing positive or negative for CPV and owned-dog CPV case occurrence (present or absent), for owned-dog cases occurring in the same year as wild-dog sampling, and across the entire owned dog sample period. Chi-squared $(\chi 2)$ analysis was performed to test associations between wild-dog observations (present or absent) and categorical variables. For all statistical tests, a $p$-value of $<0.05$ was used to determine significance.

\section{Results}

\subsection{Wild-Dog Sampling}

Tissue samples from 171 wild dogs collected between 2012 and 2015 were available for PCR testing. Details of the cadavers sampled are reported in Table 2, and maps of the regions where wild dogs were trapped are depicted in Figures 1-3.

\subsection{DNA Detection and Quantification}

Canine DNA was identified in 170/171 wild-dog cadaver samples, and CPV DNA was amplified in $4.7 \%(8 / 170)$ of the remaining samples analyzed. The viral load of CPV DNA in the samples ranged from $3.41 \times 10^{1}$ to $1.95 \times 10^{7}$ copies $/ \mu L$ (Table 3 ). 
Table 2. Australian wild-dog cadavers made available for PCR testing for canine parvovirus DNA, and test results, categorized by state of origin, sex, age and year trapped.

\begin{tabular}{|c|c|c|c|c|c|c|c|c|}
\hline Category & Variable & $\begin{array}{l}\text { No. Dogs } \\
\text { Sampled }\end{array}$ & Percentage & $\begin{array}{l}\text { No. Dogs } \\
\text { Negative }\end{array}$ & $\begin{array}{l}\text { No. Dogs } \\
\text { Positive }\end{array}$ & Chi2 & DF & $p$-Value \\
\hline \multirow[t]{4}{*}{ State } & QLD & 146 & 85.4 & 136 & 8 & 1.05 & 1 & 0.3051 \\
\hline & NSW & 18 & 10.5 & 18 & 0 & & & \\
\hline & NR & 7 & 4.1 & & & & & \\
\hline & Total & 171 & & & & & & \\
\hline \multirow[t]{4}{*}{ Sex } & Male & 76 & 44.4 & 68 & 4 & 0.08 & 1 & 0.7833 \\
\hline & Female & 87 & 50.9 & 83 & 4 & & & \\
\hline & NR & 8 & 4.7 & & & & & \\
\hline & Total & 171 & & & & & & \\
\hline \multirow[t]{9}{*}{ Age } & $\begin{array}{c}<6 \\
\text { months }\end{array}$ & 44 & 25.7 & 42 & 2 & 3.86 & 4 & 0.425 \\
\hline & $\begin{array}{c}\text { 6-12 } \\
\text { months }\end{array}$ & 44 & 25.7 & 40 & 3 & & & \\
\hline & $1-2$ years & 34 & 19.9 & 33 & 0 & & & \\
\hline & $2-5$ years & 14 & 8.2 & 13 & 1 & & & \\
\hline & $>5$ years & 17 & 9.9 & 14 & 2 & & & \\
\hline & NR & 18 & 10.5 & & & & & \\
\hline & Total & 171 & & & & & & \\
\hline & 2012 & 2 & 1.2 & 2 & 0 & 0.91 & 3 & 0.8227 \\
\hline & 2013 & 63 & 36.8 & 58 & 4 & & & \\
\hline \multirow{4}{*}{$\begin{array}{c}\text { Year } \\
\text { captured }\end{array}$} & 2014 & 90 & 52.6 & 85 & 4 & & & \\
\hline & 2015 & 9 & 5.3 & 9 & 0 & & & \\
\hline & NR & 7 & 4.1 & & & & & \\
\hline & Total & 171 & & & & & & \\
\hline
\end{tabular}

$\mathrm{NR}=$ not recorded, $\mathrm{QLD}=$ Queensland, NSW = New South Wales, Chi2 = Chi squared statistic, $\mathrm{DF}=$ degrees of freedom. Seven dogs did not have corresponding location data, and sex, age and date trapped were not available for 8, 18 and 7 samples, respectively. While these were included in the PCR testing, they were excluded from the respective statistical analysis, for which their data were unavailable.

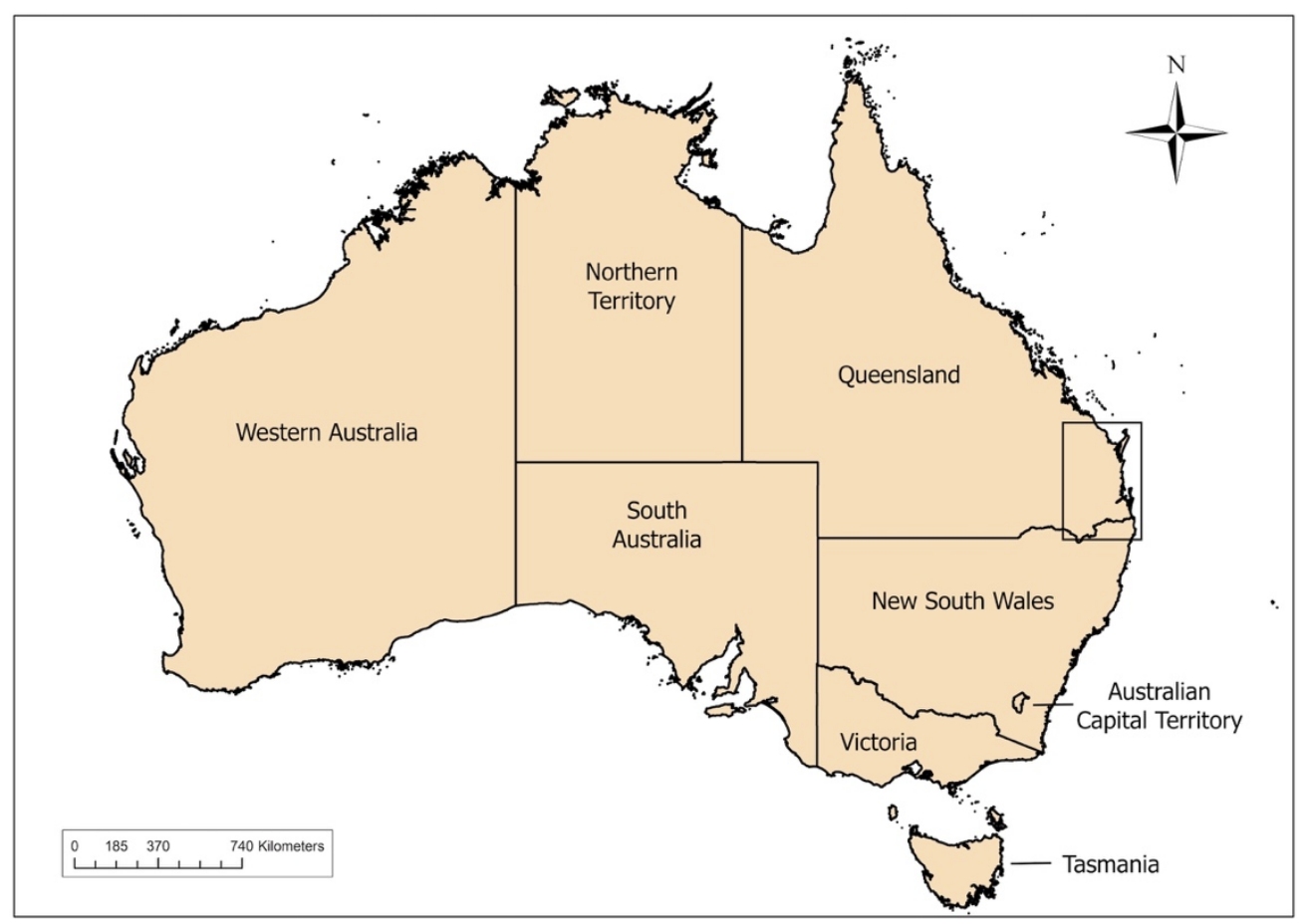

Figure 1. Region of wild-dog sampling (inset) between 2012 and 2015, in South East Queensland and Northeast New South Wales, Australia. 


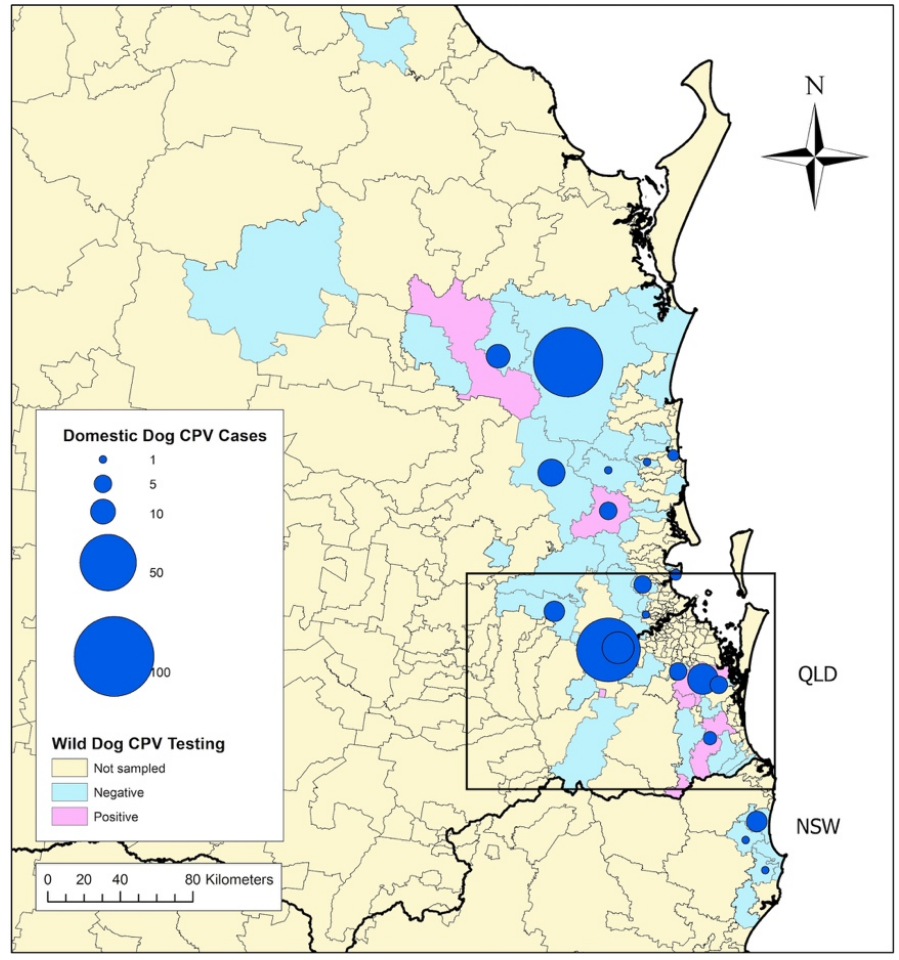

Figure 2. Distribution and frequency of canine parvovirus cases in domestic dogs reported by veterinarians on the Disease WatchDog ${ }^{\circledR}$ national disease surveillance system between 2009 and 2015, and postcodes where wild dogs, sampled between 2012 and 2015, tested positive or negative to canine parvovirus as determined by polymerase chain reaction. Map represents South East Queensland (QLD) and Northeast New South Wales (NSW), Australia. Inset depicts area represented in Figure 3.

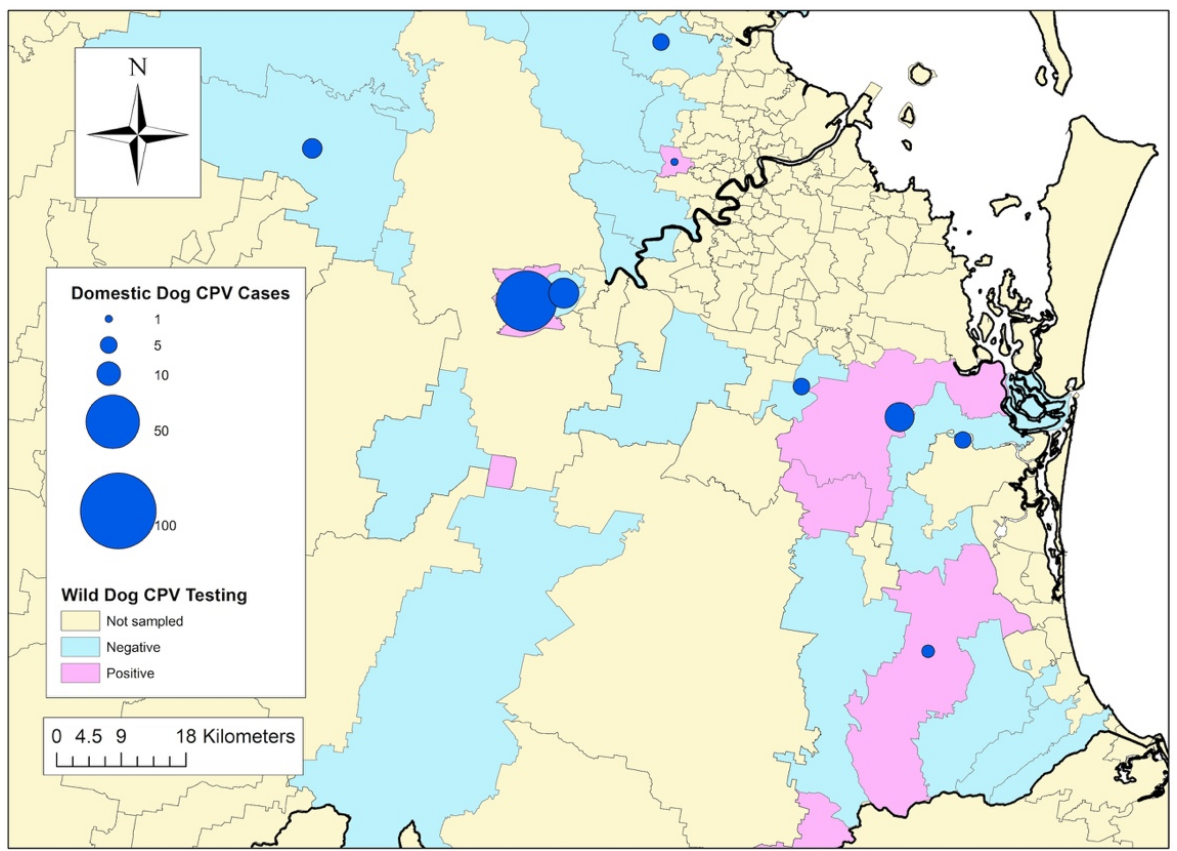

Figure 3. Distribution and frequency of canine parvovirus cases in domestic dogs reported by veterinarians on the Disease WatchDog ${ }^{\circledR}$ national disease surveillance system between 2009 and 2015, and postcodes where wild dogs, sampled between 2012 and 2015, tested positive or negative for canine parvovirus, as determined by polymerase chain reaction. Map represents Brisbane and south of Brisbane, to the border of Queensland (QLD) and New South Wales (NSW), Australia. 
Table 3. Wild-dog samples testing positive for canine parvovirus DNA by quantitative PCR.

\begin{tabular}{|c|c|c|c|c|c|c|c|c|}
\hline \multirow[b]{2}{*}{$\begin{array}{c}\text { GenBank } \\
\text { Accession No. }\end{array}$} & \multirow[b]{2}{*}{$\begin{array}{l}\text { Sample } \\
\text { ID }\end{array}$} & \multirow[b]{2}{*}{ Sex } & \multicolumn{5}{|c|}{ Location Captured } & \multirow[b]{2}{*}{$\begin{array}{l}\text { Viral Copies } \\
\text { per } \mu \mathrm{L} / \mathrm{DNA}\end{array}$} \\
\hline & & & Age & $\begin{array}{c}\text { Date } \\
\text { Captured }\end{array}$ & Region & Postcode & State Locality & \\
\hline MT447094 & WD29 & $\mathrm{M}$ & $<6$ months & 25/11/13 & Woodford & 4514 & South East QLD & $2.89 \times 10^{3}$ \\
\hline MT447095 & WD46 & M & $6-12$ months & $28 / 2 / 14$ & The Gap & 4061 & Brisbane QLD & $2.05 \times 10^{4}$ \\
\hline MT447096 & WD48 & $\mathrm{F}$ & $>5$ years & $5 / 2 / 13$ & Tamborine & 4270 & South East QLD & $1.95 \times 10^{7}$ \\
\hline MT447097 & WD49 & M & $>5$ years & $15 / 5 / 14$ & Nerang & 4211 & Gold Coast QLD & $1.57 \times 10^{6}$ \\
\hline MT447098 & WD50 & M & $2-5$ years & $24 / 8 / 13$ & Beenleigh & 4207 & South East QLD & $6.56 \times 10^{5}$ \\
\hline MT447099 & WD51 & $\mathrm{F}$ & $<6$ months & $27 / 11 / 13$ & Ipswich & 4305 & South East QLD & $2.19 \times 10^{4}$ \\
\hline NA & WD58 & $\mathrm{F}$ & $6-12$ months & $2 / 3 / 14$ & Goomeri & 4601 & South East QLD & $4.08 \times 10^{1}$ \\
\hline NA & WD59 & $\mathrm{F}$ & $6-12$ months & $26 / 2 / 14$ & The Gap & 4061 & Brisbane QLD & $3.41 \times 10^{1}$ \\
\hline
\end{tabular}

\subsection{Geography and Prevalence of Wild-Dog Exposure to CPV}

CPV DNA was amplified from eight wild dogs from seven different postcodes of QLD, but from no dogs from NSW. However, CPV detection between the states of NSW and QLD was not statistically different $\left(\chi^{2}=1.05, \mathrm{df}=1, p=0.3051\right)$, nor was any difference based on $\operatorname{sex}\left(\chi^{2}=0.08, \mathrm{df}=1, p=0.7833\right)$, age $\left(\chi^{2}=3.86, \mathrm{df}=4, p=0.425\right)$ or the year in which the dogs were captured $\left(\chi^{2}=0.91, \mathrm{df}=3\right.$, $p=0.8227$ ) (Table 2).

\subsection{Association between CPV Exposure in Wild Dogs and CPV Cases in Owned Dogs}

In total, wild dogs were sampled from 57 different postcodes. Postcodes with one or more wild dogs testing positive to CPV were 8.63 times more likely to have reported CPV cases in owned dogs in the same year $(p=0.0332)$ and 6.43 times more likely across the entire owned-dog case sampling period $(p=0.0350)($ Table 4$)$.

Table 4. Frequency of postcodes with wild dogs testing positive or negative for canine parvovirus (CPV) and domestic-dog CPV case occurrence (present or absent). Wild-dog sampling occurred between 2012 and 2015, and domestic-dog cases were reported between 2009 and 2015.

\begin{tabular}{ccccccc}
\hline $\begin{array}{c}\text { Domestic-Dog CPV } \\
\text { Cases }\end{array}$ & $\begin{array}{c}\text { Domestic-Dog } \\
\text { CPV Case } \\
\text { Occurrence }\end{array}$ & Positive & Negative & Total & $\begin{array}{c}\text { Odds } \\
\text { Ratio }\end{array}$ & $p$-value \\
\hline In all years between & Present & 5 & 14 & 19 & 6.43 & 0.0350 \\
2009 and 2015 & Absent & 2 & 36 & 38 & & \\
In same year as & Total & 7 & 50 & 57 & & \\
wild-dog sampling & Present & 3 & 4 & 7 & 8.63 & 0.0332 \\
in postcode & Total & 4 & 46 & 50 & & \\
\hline
\end{tabular}

\subsection{Wild-Dog CPV VP2 Sequencing and Phylogenetic Analysis}

Of the eight dogs in which CPV DNA was amplified by qPCR, VP2 sequencing was successful for six dogs and unsuccessful in the two dogs with the lowest viral loads (Table 3). Phylogenetic analysis revealed that three of the six wild-dog sequences were identical and all six were closely related, belonging to a clade of CPV-2a viruses comprising those from wild dogs, as well as viruses from dogs with parvoviral enteritis, in three different states of Australia (Victoria, NSW and QLD) (Figure 4). Viruses in this clade were characterized by the VP2 mutation (Thr-21-Ala) that differed from all other variants analyzed (Supplementary Materials Table S1). One of the viruses in this clade (GenBank accession no. MN259063) was collected from an owned dog with parvoviral enteritis, approximately 
$10 \mathrm{~km}$ from the capture location of one of the wild dogs (WD50) 3.5 years after the wild dog was culled (Figure 4 and Supplementary Materials Table S1).

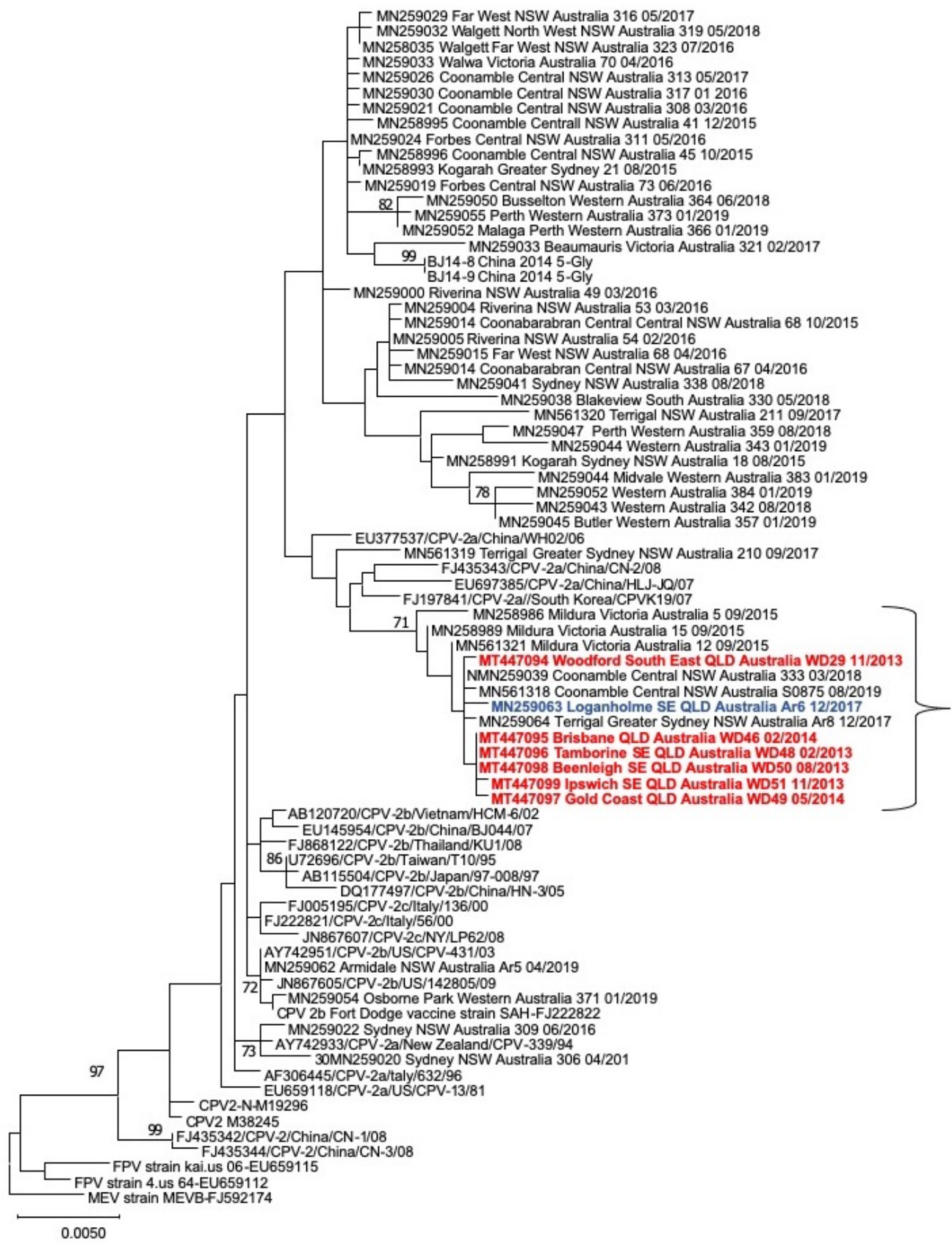

Figure 4. Phylogeny of CPV VP2 sequences from wild dogs in Australia (red) and a domestic dog (blue) within $10 \mathrm{~km}$ of the wild-dog sampling. The evolutionary history was inferred by using the Maximum Likelihood method and Tamura three-parameter model with 1000 bootstrap replicates [45]. Bootstrap values $>70 \%$ are shown on the branches. The tree with the highest log likelihood (-4045.79) is shown. The tree is drawn to scale, with branch lengths measured in the number of substitutions per site.

\section{Discussion}

This study reports the first detection of CPV in wild-dog populations in Australia and provides phylogenetic evidence that a CPV strain from a wild-dog population was closely related to a strain from a domestic dog with parvoviral enteritis in close proximity. CPV strains from wild dogs were also closely related to viruses from other owned dogs collected over a large region of Eastern Australia. 
The viruses in this clade were characterized by the VP2 protein signature 21-Ala, 297-Ala, 324-Iso and 555-Val. Two of these residues (297-Ala and 555-Val) are common, well-characterized mutations among Australian CPV strains compared to the original CPV-2 virus that emerged in dogs in the late 1970s [46]. Another VP2 residue (324-Iso) in the wild-dog strains is common in Asian strains of CPV [47] and was recently identified in owned dogs in Australia [42]. The finding of this mutation in CPV strains from wild dogs further suggests introduction or circulation of Asian strains in Australia. The Thr-21-Ala mutation, present in the VP2 sequences from all of the wild dogs, was also recently identified as a novel mutation among CPVs from owned dogs in Australia [42]. The similarity of the wild-dog VP2 sequences to those from owned dogs suggests viral transmission between these two populations, although the directionality is uncertain.

Only wild dogs from SEQ and not Northern NSW tested positive for CPV, which is likely due to the smaller sample size for NSW (versus QLD), but may also reflect different risk factors for infection between these populations. Proximity to free-ranging owned dogs may be a risk factor for CPV infection in wild dogs [48]. However, our study did not investigate owned-dog population distribution or ranging behaviors, so such a transmission pathway cannot be directly assessed here. It is possible that a higher proportion of free-ranging owned dogs in an area could lead to increased infection rates of the domestic-dog population in those areas, but this requires further investigation. Close proximity to human settlements may also increase risk for CPV exposure in wild carnivores; however, previous studies have failed to demonstrate this to be statistically significant $[32,36,49]$ or have shown no increased risk [50]. Conversely, wild-carnivore populations may have parvovirus infection cycles independent of domestic carnivores [51], and this may also be the case for some wild-dog populations in Australia; more research is needed to determine this.

No difference in age was observed between CPV-positive and -negative wild dogs, despite younger age being an identified risk factor for CPV infection and disease in unvaccinated domestic dogs [52,53] and wild canids (wolves) [54]. This may be because the method of CPV detection used in our study did not differentiate between active and recovered infections. Most (58\%, 88/153) wild dogs trapped were $<12$ months old, which may have increased the likelihood of detecting recent or active infections and also likely reflects the shorter lifespan of wild dogs versus domestic dogs. Mortality rates from CPV in wild dogs have never been reported; however, CPV disease in young animals has been implicated in reduction of population renewal in gray wolves: the proportion of pups live-trapped each year (which had declined between 1984 and 2004) correlated with increasing CPV antibody prevalence $\left(r^{2}=0.51 ; p<0.01\right)$ [54]. CPV might also play a role in population reduction in wild dogs in Australia. Our finding of no difference between the year that wild dogs were sampled suggests that CPV may be endemic in these populations.

We identified a significantly increased risk for domestic-dog CPV cases in geographical regions where wild-dog CPV infection was also detected. The finding of a closely related CPV strain in an owned dog collected from the same geographic region several years after detection in wild dogs suggests both low viral diversity over time and that ongoing transmission of CPV might have been occurring between the wild-dog populations in this area and neighboring owned-dog populations. Interpopulation disease transmission could be unidirectional from either population, or bidirectional [32]. Interpopulation transmission could be facilitated by roaming dogs from either or both populations entering the others' territories and transmitting virus via fomites or directly from an infected animal through defecation. Peri-urban wild dogs in Australia have been found to have home ranges of around $17 \mathrm{~km}^{2}$, travel an average of $7 \mathrm{~km} /$ day [55] and often spend time in urban habits [56], making CPV-transmission between wild and domestic dogs likely in these areas. Fomite transmission due to human movement or other domestic/wild/feral species traversing the two territories may also occur. The ability for CPV to survive for protracted periods in the environment makes indirect transmission more likely [57].

Our detected prevalence of CPV exposure (5.3\%) is much lower than that reported by serological testing of a range of wild canids in the Yellowstone National Park, USA (98\%); Canadian Rocky Mountains (95\%); Montana, USA (65\%); Chile (49\%); Portugal (38\%); and Spain (17.2\%) [50,58-60]. 
The true level of CPV exposure in the wild-dog population we tested is likely to be higher. However, a limitation of our study was that we only had access to wild-dog cadaver tissue, and blood for serological testing was not available. Serological testing is able to detect prior CPV exposure in individuals, with high sensitivity, due to long-lasting seropositivity following natural infection [6], whereas PCR is very sensitive to detect CPV DNA, but successful amplification depends on the availability of infected monocytes being present in the sample tissue. The viral loads obtained from six of the eight positive samples were similar to the range reported in samples collected from lymph nodes of clinically affected FPV-positive cats [30], suggesting that these six dogs were undergoing active CPV infections, while the remaining two were latently infected. Given that the epidemiological features of CPV include fecal shedding in high viral loads, environmental persistence and a high degree of contagiousness, it is likely that a larger proportion of wild dogs are exposed than are reflected in our results. The ongoing culling programs from which our samples were sourced, and the resulting reduction of wild-dog population size, may have also reduced the transmission of CPV in these populations. Serological testing of wild dogs throughout Australia is therefore warranted to determine whether actual CPV prevalence is in fact higher than our findings reflect.

\section{Conclusions}

The detection of CPV in this small population of peri-urban wild dogs suggests that parvoviral infection might be widespread among sympatric populations of wild and owned dogs in Australia. The finding of related strains of CPV in wild and owned dogs in Australia suggests that viral transmission might be occurring between these two populations, although the directionality is uncertain. It is possible that wild dogs could be responsible for some outbreaks of disease among domestic-dog populations, particularly at the urban fringe, or that infection from domestic-dog populations can spill over to wild dogs. Further research is warranted to definitively determine if CPV transmission is occurring between these populations.

Supplementary Materials: The following are available online at http://www.mdpi.com/1999-4915/12/6/663/s1. Table S1: Amino acid substitutions in the VP2 region of strains of canine parvovirus (CPV) detected from tongue tissue of wild-dog cadavers from Northern New South Wales and South East Queensland, Australia (2013 to 2014), and in feces from dogs with confirmed parvoviral enteritis (2015 to 2019), compared to reference strains of CPV and feline parvovirus (FPV).

Author Contributions: Conceptualization, M.K., M.P.W. and V.R.B.; data curation, M.K., L.H., M.C. and E.K.; formal analysis, M.K. and V.R.B.; funding acquisition, M.K.; investigation, M.K., L.H., M.C. and E.K.; methodology, M.K., M.C., M.P.W. and V.R.B.; project administration, M.K.; resources, M.K. and V.R.B.; supervision, M.C., M.P.W and V.R.B.; validation, M.K., M.P.W. and V.R.B.; visualization, M.K. and V.R.B.; writing-original draft, M.K. and V.R.B.; writing-review and editing, M.K., L.H., M.C., E.K., M.P.W. and V.R.B. All authors have read and agreed to the published version of the manuscript.

Funding: This research was funded by the Australian Companion Animal Health Fund, grant number 008/2019. The APC was funded by The University of Sydney.

Acknowledgments: The authors wish to thank the VetCompass consortium for access to data from the Disease WatchDog ${ }^{\circledR}$ database. Thanks are also given to the many veterinary clinic contributors of case reports to Disease WatchDog ${ }^{\circledR}$ and the local government officers and individuals involved in the wild-dog capture, without whom this research would not have been possible. The research in this paper was completed in partial fulfilment for the requirements of a PhD degree at The University of Sydney, by the lead author.

Conflicts of Interest: The authors declare no conflict of interest. The funders had no role in the design of the study; in the collection, analyses or interpretation of data; in the writing of the manuscript; or in the decision to publish the results.

\section{References}

1. Cotmore, S.F.; Agbandje-McKenna, M.; Canuti, M.; Chiorini, J.A.; Eis-Hubinger, A.-M.; Hughes, J.; Mietzsch, M.; Modha, S.; Ogliastro, M.; Pénzes, J.J.; et al. ICTV Virus Taxonomy Profile: Parvoviridae. J. Gen. Virol. 2019, 100, 367-368. [CrossRef] [PubMed] 
2. Behdenna, A.; Lembo, T.; Calatayud, O.; Cleaveland, S.; Halliday, J.E.B.; Packer, C.; Lankester, F.; Hampson, K.; Craft, M.E.; Czupryna, A.; et al. Transmission ecology of canine parvovirus in a multi-host, multi-pathogen system. Proc. R. Soc. B Biol. Sci. 2019, 286, 20182772. [CrossRef] [PubMed]

3. Calatayud, O.; Esperón, F.; Cleaveland, S.; Biek, R.; Keyyu, J.; Eblate, E.; Neves, E.; Lembo, T.; Lankester, F. Carnivore Parvovirus Ecology in the Serengeti Ecosystem: Vaccine Strains Circulating and New Host Species Identified. J. Virol. 2019, 93, 1-18. [CrossRef] [PubMed]

4. Calatayud, O.; Esperón, F.; Velarde, R.; Oleaga, Á.; Llaneza, L.; Ribas, A.; Negre, N.; Torre, A.; Rodríguez, A.; Millán, J. Genetic characterization of Carnivore Parvoviruses in Spanish wildlife reveals domestic dog and cat-related sequences. Transbound. Emerg. Dis. 2019, 1-9. [CrossRef] [PubMed]

5. Chen, C.-C.; Chang, A.-M.; Wada, T.; Chen, M.-T.; Tu, Y.-S. Distribution of Carnivore protoparvovirus 1 in free-living leopard cats (Prionailurus bengalensis chinensis) and its association with domestic carnivores in Taiwan. PLoS ONE 2019, 14, e0221990. [CrossRef]

6. Gese, E.M.; Schultz, R.D.; Rongstad, O.J.; Andersen, D.E. Prevalence of Antibodies against Canine Parvovirus and Canine Distemper Virus in Wild Coyotes in Southeastern Colorado. J. Wildl. Dis. 1991, 27, 320-323. [CrossRef]

7. Ikeda, Y.; Mochizuki, M.; Naito, R.; Nakamura, K.; Miyazawa, T.; Mikami, T.; Takahashi, E. Predominance of Canine Parvovirus (CPV) in Unvaccinated Cat Populations and Emergence of New Antigenic Types of CPVs in Cats. Virology 2000, 278, 13-19. [CrossRef]

8. Steinel, A.; Munson, L.; van Vuuren, M.; Truyen, U. Genetic characterization of feline parvovirus sequences from various carnivores. J. Gen. Virol. 2000, 81, 345-350. [CrossRef]

9. Truyen, U.; Platzer, G.; Parrish, C.R. Antigenic type distribution among canine parvoviruses in dogs and cats in Germany. Vet. Rec. 1996, 138, 365-366. [CrossRef]

10. Van Arkel, A.; Kelman, M.; West, P.; Ward, M.P. The relationship between reported domestic canine parvovirus cases and wild canid distribution. Heliyon 2019, 5, e02511. [CrossRef]

11. Zarnke, R.L.; Ballard, W.B. Serologic survey for selected microbial pathogens of wolves in Alaska, 1975-1982. J. Wildl. Dis. 1987, 23, 77-85. [CrossRef] [PubMed]

12. Allison, A.B.; Kohler, D.J.; Fox, K.A.; Brown, J.D.; Gerhold, R.W.; Shearn-Bochsler, V.I.; Dubovi, E.J.; Parrish, C.R.; Holmes, E.C. Frequent Cross-Species Transmission of Parvoviruses among Diverse Carnivore Hosts. J. Virol. 2013, 87, 2342-2347. [CrossRef] [PubMed]

13. Shackelton, L.A.; Parrish, C.R.; Truyen, U.; Holmes, E.C. High rate of viral evolution associated with the emergence of carnivore parvovirus. Proc. Natl. Acad. Sci. USA 2005, 102, 379-384. [CrossRef]

14. Mylonakis, M.; Kalli, I.; Rallis, T. Canine parvoviral enteritis: an update on the clinical diagnosis, treatment, and prevention. Vet. Med. Res. Rep. 2016, 7, 91-100. [CrossRef] [PubMed]

15. Allison, A.B.; Kohler, D.J.; Ortega, A.; Hoover, E.A.; Grove, D.M.; Holmes, E.C.; Parrish, C.R. Host-Specific Parvovirus Evolution in Nature Is Recapitulated by In Vitro Adaptation to Different Carnivore Species. Plos Pathog. 2014, 10, e1004475. [CrossRef]

16. Allison, A.B.; Harbison, C.E.; Pagan, I.; Stucker, K.M.; Kaelber, J.T.; Brown, J.D.; Ruder, M.G.; Keel, M.K.; Dubovi, E.J.; Holmes, E.C.; et al. Role of Multiple Hosts in the Cross-Species Transmission and Emergence of a Pandemic Parvovirus. J. Virol. 2012, 86, 865-872. [CrossRef]

17. Steinel, A.; Parrish, C.R.; Bloom, M.E.; Truyen, U. Parvovirus infections in wild carnivores. J. Wildl. Dis. 2001, 37, 594-607. [CrossRef]

18. Truyen, U.; Gruenberg, A.; Chang, S.-F.; Obermaier, B.; Veijalainen, P.; Parrish, C.R. Evolution of the Feline-Subgroup Parvoviruses and the Control of Canine Host Range In Vivo. J. Virol. 1995, 69, 9. [CrossRef]

19. Truyen, U.; Evermann, J.F.; Vieler, E.; Parrish, C.R. Evolution of canine parvovirus involved loss and gain of feline host range. Virology 1996, 215, 186-189. [CrossRef]

20. Kelman, M.; Ward, M.P.; Barrs, V.R.; Norris, J.M. The geographic distribution and financial impact of canine parvovirus in Australia. Transbound. Emerg. Dis. 2019, 66, 299-311. [CrossRef]

21. Zourkas, E.; Ward, M.P.; Kelman, M. Canine parvovirus in Australia: A comparative study of reported rural and urban cases. Vet. Microbiol. 2015, 181, 198-203. [CrossRef] [PubMed]

22. Mulley, R.C.; Claxton, P.D.; Feilen, C.P. A serological survey of some infectious diseases in the red fox (Vulpes vulpes) in New South Wales. Proc. 4th Int. Conf. Wildl. Dis. Assoc. 1981, 44-46. 
23. Gabriele-Rivet, V.; Arsenault, J.; Wilhelm, B.; Brookes, V.J.; Newsome, T.M.; Ward, M.P. A Scoping Review of Dingo and Wild-Living Dog Ecology and Biology in Australia to Inform Parameterisation for Disease Spread Modelling. Front. Vet. Sci. 2019, 6, 1-14. [CrossRef] [PubMed]

24. Harriott, L. Prevalence, Risk Factors, and Geographical Distribution of Zoonotic Pathogens Carried by Peri-urban Wild Dogs. Ph.D. Thesis, The University of Queensland, Brisbane, Australia, 2018.

25. Jackson, S.M.; Groves, C.P.; Fleming, P.J.S.; Aplin, K.P.; Eldridge, M.D.B.; Gonzalez, A.; Helgen, K.M. The Wayward Dog: Is the Australian native dog or Dingo a distinct species? Zootaxa 2017, 4317, 201. [CrossRef]

26. Kinnear, J.E.; Sumner, N.R.; Onus, M.L. The red fox in Australia-an exotic predator turned biocontrol agent. Biol. Conserv. 2002, 108, 335-359. [CrossRef]

27. Glen, A.S.; Dickman, C.R. Complex interactions among mammalian carnivores in Australia, and their implications for wildlife management. Biol. Rev. 2005, 80, 387. [CrossRef]

28. Brailey, J.; Jenkins, D.; Aghazadeh, M.; Slapeta, J.; Beatty, J.A.; Barrs, V.R. Feral carnivores are reservoirs of Carnivore protoparvovirus 1 in Australia. Ecvim-Ca Congr. St Julian'smalta 2017.

29. Haynes, S.; Holloway, S. Identification of parvovirus in the bone marrow of eight cats. Aust. Vet. J. 2012, 90, 136-139. [CrossRef]

30. Van Brussel, K.; Carrai, M.; Lin, C.; Kelman, M.; Setyo, L.; Aberdein, D.; Brailey, J.; Lawler, M.; Maher, S.; Plaganyi, I.; et al. Distinct Lineages of Feline Parvovirus Associated with Epizootic Outbreaks in Australia, New Zealand and the United Arab Emirates. Viruses 2019, 11, 1155. [CrossRef]

31. Laurenson, K.; Sillero-Zubiri, C.; Thompson, H.; Shiferaw, F.; Thirgood, S.; Malcolm, J. Disease as a threat to endangered species: Ethiopian wolves, domestic dogs and canine pathogens. Anim. Conserv. 1998, 1, 273-280. [CrossRef]

32. López-Pérez, A.M.; Moreno, K.; Chaves, A.; Ibarra-Cerdeña, C.N.; Rubio, A.; Foley, J.; List, R.; Suzán, G.; Sarmiento, R.E. Carnivore Protoparvovirus 1 at the Wild-Domestic Carnivore Interface in Northwestern Mexico. EcoHealth 2019, 16, 502-511. [CrossRef]

33. Mainka, S.A.; Xianmeng, Q.; Tingmei, H.; Appel, M.J. Serologic Survey of Giant Pandas (Ailuropoda melanoleuca), and Domestic Dogs and Cats in the Wolong Reserve, China. J. Wildl. Dis. 1994, 30, 86-89. [CrossRef] [PubMed]

34. Woodroffe, R.; Prager, K.C.; Munson, L.; Conrad, P.A.; Dubovi, E.J.; Mazet, J.A.K. Contact with Domestic Dogs Increases Pathogen Exposure in Endangered African Wild Dogs (Lycaon pictus). PLoS ONE 2012, 7, e30099. [CrossRef] [PubMed]

35. Acosta-Jamett, G.; Cunningham, A.A.; Bronsvoort, B.D.; Cleaveland, S. Serosurvey of canine distemper virus and canine parvovirus in wild canids and domestic dogs at the rural interface in the Coquimbo Region, Chile. Eur. J. Wildl. Res. 2015, 61, 329-332. [CrossRef]

36. Truyen, U.; Müller, T.; Heidrich, R.; Tackmann, K.; Carmichael, L.E. Survey on viral pathogens in wild red foxes (Vulpes vulpes) in Germany with emphasis on parvoviruses and analysis of a DNA sequence from a red fox parvovirus. Epidemiol. Infect. 1998, 121, 433-440. [CrossRef] [PubMed]

37. Miyazawa, T.; Ikeda, Y.; Nakamura, K.; Naito, R.; Mochizuki, M.; Tohya, Y.; Vu, D.; Mikami, T.; Takahashi, E. Isolation of Feline Parvovirus from Peripheral Blood Mononuclear Cells of Cats in Northern Vietnam. Microbiol. Immunol. 1999, 43, 609-612. [CrossRef] [PubMed]

38. Norja, P.; Hokynar, K.; Aaltonen, L.-M.; Chen, R.; Ranki, A.; Partio, E.K.; Kiviluoto, O.; Davidkin, I.; Leivo, T.; Eis-Hubinger, A.M.; et al. Bioportfolio: Lifelong persistence of variant and prototypic erythrovirus DNA genomes in human tissue. Proc. Natl. Acad. Sci. USA 2006, 103, 7450-7453. [CrossRef]

39. Peters, I.R.; Peeters, D.; Helps, C.R.; Day, M.J. Development and application of multiple internal reference (housekeeper) gene assays for accurate normalisation of canine gene expression studies. Vet. Immunol. Immunopathol. 2007, 117, 55-66. [CrossRef] [PubMed]

40. Decaro, N.; Elia, G.; Martella, V.; Desario, C.; Campolo, M.; Trani, L.D.; Tarsitano, E.; Tempesta, M.; Buonavoglia, C. A real-time PCR assay for rapid detection and quantitation of canine parvovirus type 2 in the feces of dogs. Vet. Microbiol. 2005, 105, 19-28. [CrossRef]

41. Decaro, N.; Desario, C.; Elia, G.; Martella, V.; Mari, V.; Lavazza, A.; Nardi, M.; Buonavoglia, C. Evidence for immunisation failure in vaccinated adult dogs infected with canine parvovirus type 2c. Microbiol. Q. J. Microbiol. Sci. 2008, 31, 125-130. 
42. Kwan, E.; Carrai, M.; Lanave, G.; Hill, J.; Parry, K.; Kelman, M.; Meers, J.; Decaro, N.; Beatty, J.; Martella, V.; et al. Analysis of canine parvoviruses circulating in Australia reveals predominance of variant $2 \mathrm{~b}$ strains and identifies feline parvovirus-like mutations in the capsid proteins. Transbound. Emerg. Dis. 2020. under review.

43. Ward, M.P.; Kelman, M. Companion animal disease surveillance: A new solution to an old problem? Spat. Spatio-Temporal Epidemiol. 2011, 2, 147-157. [CrossRef] [PubMed]

44. Australian Bureau of Statistics 1270.0.55.003-Australian Statistical Geography Standard (ASGS): Volume 3-Non ABS Structures, July 2016. Available online: https://www.abs.gov.au/AUSSTATS/abs@.nsf/ DetailsPage/1270.0.55.003July\%202016?OpenDocument (accessed on 18 June 2020).

45. Tamura, K. Estimation of the number of nucleotide substitutions when there are strong transition-transversion and G+C-content biases. Mol. Biol. Evol. 1992, 9, 678-687. [CrossRef] [PubMed]

46. Meers, J.; Kyaw-Tanner, M.; Bensink, Z.; Zwijnenberg, R. Genetic analysis of canine parvovirus from dogs in Australia. Aust. Vet. J. 2007, 85, 392-396. [CrossRef]

47. Wang, J.; Lin, P.; Zhao, H.; Cheng, Y.; Jiang, Z.; Zhu, H.; Wu, H.; Cheng, S. Continuing evolution of canine parvovirus in China: Isolation of novel variants with an Ala5Gly mutation in the VP2 protein. Infect. Genet. Evol. 2016, 38, 73-78. [CrossRef]

48. Frölich, K.; Streich, W.J.; Fickel, J.; Jung, S.; Truyen, U.; Hentschke, J.; Dedek, J.; Prager, D.; Latz, N. Epizootiologic Investigations of Parvovirus Infections in Free-ranging Carnivores from Germany. J. Wildl. Dis. 2005, 41, 231-235. [CrossRef]

49. Knobel, D.L.; Butler, J.R.A.; Lembo, T.; Critchlow, R.; Gompper, M.E. Dogs, disease, and wildlife. In Free-Ranging Dogs and Wildlife Conservation; Gompper, M.E., Ed.; Oxford University Press: Oxford, UK, 2013; pp. 144-169. ISBN 978-0-19-966321-7.

50. Nelson, B.; Hebblewhite, M.; Ezenwa, V.; Shury, T.; Merrill, E.H.; Paquet, P.C.; Schmiegelow, F.; Seip, D.; Skinner, G.; Webb, N. Prevalence of antibodies to canine parvovirus and distemper virus in wolves in the Canadian Rocky Mountains. J. Wildl. Dis. 2012, 48, 68-76. [CrossRef]

51. Courtenay, O.; Quinnell, R.J.; Chalmers, W.S.K. Contact rates between wild and domestic canids: no evidence of parvovirus or canine distemper virus in crab-eating foxes. Vet. Microbiol. 2001, 81, 9-19. [CrossRef]

52. Houston, D.M.; Ribble, C.S.; Head, L.L. Risk factors associated with parvovirus enteritis in dogs: 283 cases (1982-1991). J. Am. Vet. Med. Assoc. 1996, 208, 542.

53. Ling, M.; Norris, J.M.; Kelman, M.; Ward, M.P. Risk factors for death from canine parvoviral-related disease in Australia. Vet. Microbiol. 2012, 158, 280-290. [CrossRef]

54. Mech, L.D.; Goyal, S.M.; Paul, W.J.; Newton, W.E. Demographic effects of canine parvovirus on a free-ranging wolf population over 30 years. J. Wildl. Dis. 2008, 44, 824-836. [CrossRef] [PubMed]

55. McNeill, A.; Leung, L.; Goullet, M.; Gentle, M.; Allen, B. Dingoes at the Doorstep: Home Range Sizes and Activity Patterns of Dingoes and Other Wild Dogs around Urban Areas of North-Eastern Australia. Animals 2016, 6, 48. [CrossRef] [PubMed]

56. Allen, B.L.; Goullet, M.; Allen, L.R.; Lisle, A.; Leung, L.K.-P. Dingoes at the doorstep: Preliminary data on the ecology of dingoes in urban areas. Landsc. Urban Plan. 2013, 119, 131-135. [CrossRef]

57. Gordon, J.C.; Angrick, E.J. Canine parvovirus: environmental effects on infectivity. Am. J. Vet. Res. 1986, 47, 1464.

58. Almberg, E.S.; Mech, L.D.; Smith, D.W.; Sheldon, J.W.; Crabtree, R.L. A Serological Survey of Infectious Disease in Yellowstone National Park's Canid Community. PLoS ONE 2009, 4, e7042. [CrossRef]

59. Santos, N.; Almendra, C.; Tavares, L. Serologic Survey for Canine Distemper Virus and Canine Parvovirus in Free-ranging Wild Carnivores from Portugal. J. Wildl. Dis. 2009, 45, 221-226. [CrossRef] [PubMed]

60. Sobrino, R.; Arnal, M.C.; Luco, D.F.; Gortázar, C. Prevalence of antibodies against canine distemper virus and canine parvovirus among foxes and wolves from Spain. Vet. Microbiol. 2008, 126, 251-256. [CrossRef] [PubMed]

(C) 2020 by the authors. Licensee MDPI, Basel, Switzerland. This article is an open access article distributed under the terms and conditions of the Creative Commons Attribution (CC BY) license (http://creativecommons.org/licenses/by/4.0/). 